\title{
Article/Artigo
}

\section{Immunohistochemical expression of oestrogen and progesterone receptors during experimental acute and chronic murine Schistosomiasis mansoni}

\author{
Expressão imunohistoquímica de receptores para estrogênio e progesterona nas fases aguda \\ e crônica da esquistossomose mansônica experimental em camundongos
}

\author{
Fawzia Ahmed Habib ${ }^{1}$, Mayssa Mohamed $\mathrm{Zaki}^{2}$, Amany Ahmed Abd El-Aal ${ }^{3}$, Maha Dia Eldean Safwat ${ }^{4}$ \\ and Magda Ahmed El Domiaty ${ }^{4}$
}

\begin{abstract}
Introduction: The responsibility of Schistosoma mansoni in female infertility is still controversial. This study was conducted to evaluate the effect of acute and chronic schistosomiasis mansoni infection on the endometrium using immunohistochemical analysis of uterine hormone receptor expression. Methods: Twenty-four nonpregnant swiss albino mice were divided into three groups: control, noninfected; acute; and chronic Schistosoma mansoni infection. Histological sections of uterine specimens were examined by light microscope with an image analyzing system to detect structural histological, estrogen receptor (ER) and progesterone receptor (PR) expression in the endometrium. Results: No secretory phase was detected in the endometrium in acute and chronic Schistosoma infection. Hormone receptor expression (ER and PR) showed statistically significant differences among the groups $(\mathrm{p}<0.05)$, with significant low ER hormone expression in chronic infection, compared to control proliferative, control secretory and acute infection cases, and statistically significant high PR expression in both acute and chronic infection cases compared to the control secretory cases $(\mathrm{p}<0.05)$. Conclusions: Schistosomiasis mansoni seems to have an important impact on the hormone expression of affected women. Further studies to explore the mechanism of such changes are recommended.
\end{abstract}

Key-words: Schistosoma mansoni. Endometrium. Hormone receptors. Oestrogen. Progesterone-immunohistochemistry.

\section{RESUMO}

Introdução: A responsabilidade do Schistosoma mansoni em esterilidade feminina é ainda controversa. Este estudo é conduzido para avaliar o efeito da esquistossomose mansoni aguda e crônica no endométrio usando análise de imuno-histoquímíca da expressão de receptor hormonal uterina. Métodos: Vinte e quatro camundongos fêmeas albinas suíças não grávidas foram divididas em 3 grupos (controle não-infectado, grupos agudos e crônicos infeccionados com Schistosoma mansoni). As seções histológicas de espécimes uterinos foram examinadas por microscópio leve com imagem, analisando sistema para detectar no endométrio expressões histológicas estruturais, receptor de estrogênio (ER) e receptor de progesterona (PR). Resultados: Nenhuma fase secretora foi detectada no endométrio com infecção aguda e crônica de Schistosoma. A expressão hormonal de receptor (ER e PR) mostrou diferenças estatisticamente significantes entre grupos diferentes $(p<0,05)$ com baixa significativa hormonal de ER com infecção crônica (comparado com controle proliferativo, controle secretório e casos agudos de infecção) e alta expressão de receptor de PR estatisticamente significativa em casos tanto agudos e crônicos de infecção como comparado com os casos de controle secretório $(\mathrm{P}<0,05)$. Conclusões: A esquistossomose mansoni parece ter um maior impacto em expressão hormonal das mulheres afetadas. Mais estudos para explorar o mecanismo de tais mudanças são recomendados.

Palavras-chaves: Schistosoma mansoni. Endométrio. Receptores hormonais. Oestrogen. Progesterona-imuno-histoquímica

1. Obstetrics and Gynecology Department, Faculty of Medicine, Taibah University. Saudi Arabia. 2. Parasitology Department, Faculty of Medicine, Cairo University. Egypt. 3. Parasitology Department, Faculty of Medicine, Taibah University. Saudi Arabia. 4. Anatomy Department, Faculty of Medicine, Taibah University, Saudi Arabia.

Address to: Dra. Magda Ahmed El Domiaty. Female Section/Anatomy Department/Faculty of Medicine/ Taibah University. Almadinah Almonawarah, Saudi Arabia.

Phone: 96655 957-9980

e-mail:dr_majda@hotmail.com

Received in 15/04/2010

Accepted in 12/05/2010

\section{INTRODUCTION}

Schistosomiasis is one of the most serious parasitic diseases. More than 250 million people are infected with schistosomes in tropical or subtropical regions ${ }^{1}$ and about 40 million women of childbearing age are infected ${ }^{2}$. The parasitic flukes have some unique biological features; complex life cycles, mechanisms to avoid host immune responses and an apparent reliance on host endocrine and immune signals to complete their development, maturation and egg production ${ }^{1}$.

Despite the complex pathophysiological reactions during schistosomiasis, female genital infection is an almost entirely neglected disease entity that may give rise to considerable suffering among women in areas where schistosomiasis is prevalent. Several disorders in the female genital system due to both Schistosoma haematobium and mansoni have been reported, such as complications during pregnancy and related outcomes, menstrual disorders and other problems related to the female genital system ${ }^{2-4}$. Although infertility is determined to be the result of Schistosoma infection ${ }^{5-7}$, the responsibility of schistosomiasis in female infertility is controversial.

Little is known regarding the hormonal changes associated with such infection in women. Parasites can alter hormone concentrations in their hosts, including estrogen and progesterone. Therefore, studies concerning host hormones responses to infection and the extent to which changes occur in endocrine-immune interactions following infection, mediated by the host or the parasite, are still recommended ${ }^{8}$.

Estrogen and progesterone receptors are members of the steroid receptor super family that binds the corresponding hormones that are expressed in the uterus, ovary, vagina and fallopian tubes in the female genital system. These receptors play a central role in women's fertility cycles and 
diverse reproductive events associated with the establishment and maintenance of pregnancy.

The objective of this work was to study the effect of acute and chronic Schistosoma mansoni infection on the mouse endometrium through immunohistochemical analysis of uterine hormone receptor expression.

\section{METHODS}

\section{Experimental animals infection}

Swiss albino nonpregnant female mice weighing 20-25 grams were housed in breeding cages, with a 12-hr light/dark cycle and free access to food and water. The mice were divided into 3 groups, each consisting of 8 mice: 1) control noninfected; 2) acute infection by S. mansoni; and 3) chronicinfection by S. mansoni. For infection, the mice received a dose of 70-80 S. mansoni cercariae by tail immersion. Cercariae were obtained from the Tudor Bilharz Research Institute, Cairo, Egypt. For acute infection, the mice were maintained for 8 weeks, whereas for chronic infection, the mice were maintained for 16 weeks before sacrification?

\section{Light microscopy and Immunohistochemical examination}

At the expected date, the mice were sacrificed by cervical dislocation and dissected. The uteri were extracted and fixed in $10 \%$ buffered formalin and prepared for embedding in paraffin blocks. Preparations for structural histological examination were performed by cutting serial sections and staining with hematoxylin and eosin ${ }^{10}$. Tissue blocks were cut into $6 \mu \mathrm{m}$ thick sections, deparaffinised and rehydrated. Epitope retrieval was performed using the Tris-EDTA buffer epitope retrieval method. To reduce nonspecific background staining due to endogenous peroxidase, the slides were incubated in hydrogen peroxide block for $10-15 \mathrm{~min}$. They were then washed twice in a buffer. Anti-ER and anti-PR antibodies (mouse anti-human estrogen and progesterone, Lab Vision Corporation, USA), were applied and incubated overnight in a humidity chamber. Streptavidin peroxidase was applied and incubated for 10 min at room temperature. Biotinylated goat anti-polyvalent was then applied and incubated for $10 \mathrm{~min}$ at room temperature. After each step the sections were washed four times in phosphate-buffered saline. One or two drops of $\mathrm{DAB}$ Chromagen were added to $1 \mathrm{ml}$ of $\mathrm{DAB}$ substrate, mixed by swirling and applied to the tissues, which were then incubated for 5-15 min, depending on the desired stain intensity. Lastly, the slides

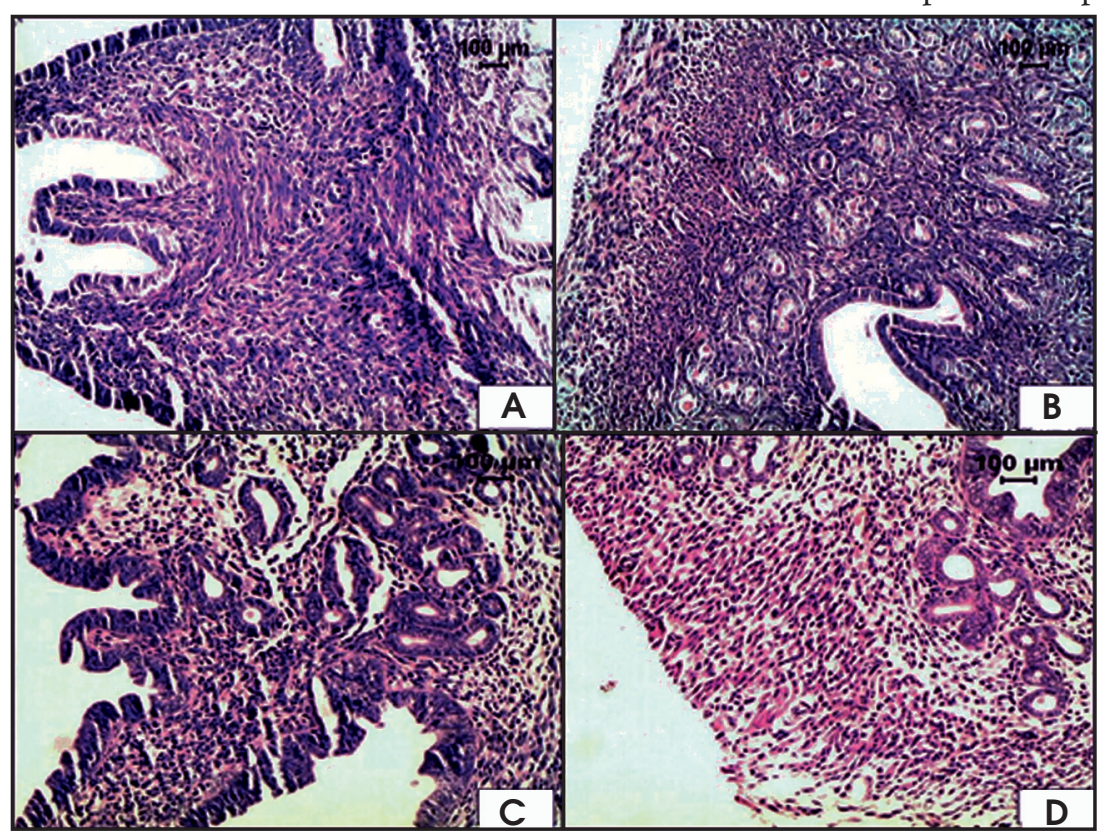

were counterstained with Mayer's haematoxylin and cover-slipped using a permanent mounting media ${ }^{11}$. Estrogen and progesterone receptor expressions were evaluated as the percentage of positive nuclei in epithelial cells of the observed field in control, acute and chronic schistosomiasis specimens, observed at high magnification (400x). Cases were classified as ER and PR positive when more than $10 \%$ of cells exhibited positive nuclear epithelial staining. The mean of three fields were chosen from each slide, so as to bestreflect the overall immunostaining of the hormone receptors contained on the entire slide. The two observers who examined the slides were blinded regarding the clinicopathological data ${ }^{12}$.

\section{Statistical analysis}

Statistical analysis was performed by one way analysis of variance (ANOVA) followed by Turkey's HSD (honestly significant difference) pair wise comparisons. The level of significance was set at $\mathrm{p}<0.05$ throughout the study. Current SPSS (version 13) statistical package was used in all statistical analysis. For each hormone receptor expression, Paired-Samples t test was used to detect significant differences between different groups ${ }^{13}$.

\section{RESULTS}

Sections of control mice uterus showed either the proliferative or the secretory phases of endometrium. The proliferative endometrium was relatively thin, consisting of stratum basalis and stratum functionalis (stratum spongiosum and stratum compactum). The glandular epithelium exhibited basally located nuclei and prominent nucleoli, while the stroma was highly cellular and devoid of collagen fibers. Some sections showed the convoluted tubular glands of the late proliferative phase with the pseudo stratified appearance. The secretory endometrium showed irregular configuration of the glands that were lined by tall columnar epithelium with basal vacuolation. The glands of the late seretory phase appeared tortuous, coiled and contained copious thick glycogen secretion. The stroma appeared highly vascular with the interstitial fluid accumulated between the cells (Figure 1, A and B).

After acute and chronic S. mansoni infection, although no granulomas were observed, the endometrium showed only the late proliferative phase with the highly cellular stroma and the convoluted tubules that showed no secretion in their lumina (Figure 1, C and D). Nuclear epithelial expression for ERs showed negative reaction in all the groups studied, whereas PR expression was negative only in the control secretory group and positive in all the other groups (Figure 2, 3).

Hormone receptor expression (ER and PR) showed statistically significant differences among the groups $(\mathrm{p}<0.05)$ (Table 1). Statistically significant low ER hormone expression occurred in chronic infection cases compared to that of control

FIGURE 1 - Photographs of histopathological sections from the uterus of control and infected groups: A) Proliferative endometrium with highly cellular stroma, some convoluted tubular glands of the late proliferative phase can be observed, B) The secretory endometrium with highly vascular stroma and coiled irregular glands that contain glycogen secretion, C) Acute and D) Chronic Schistosoma infection showing the late proliferative endometrium with the highly cellular stroma and the nonsecretory convoluted tubules (HE, 200x). 


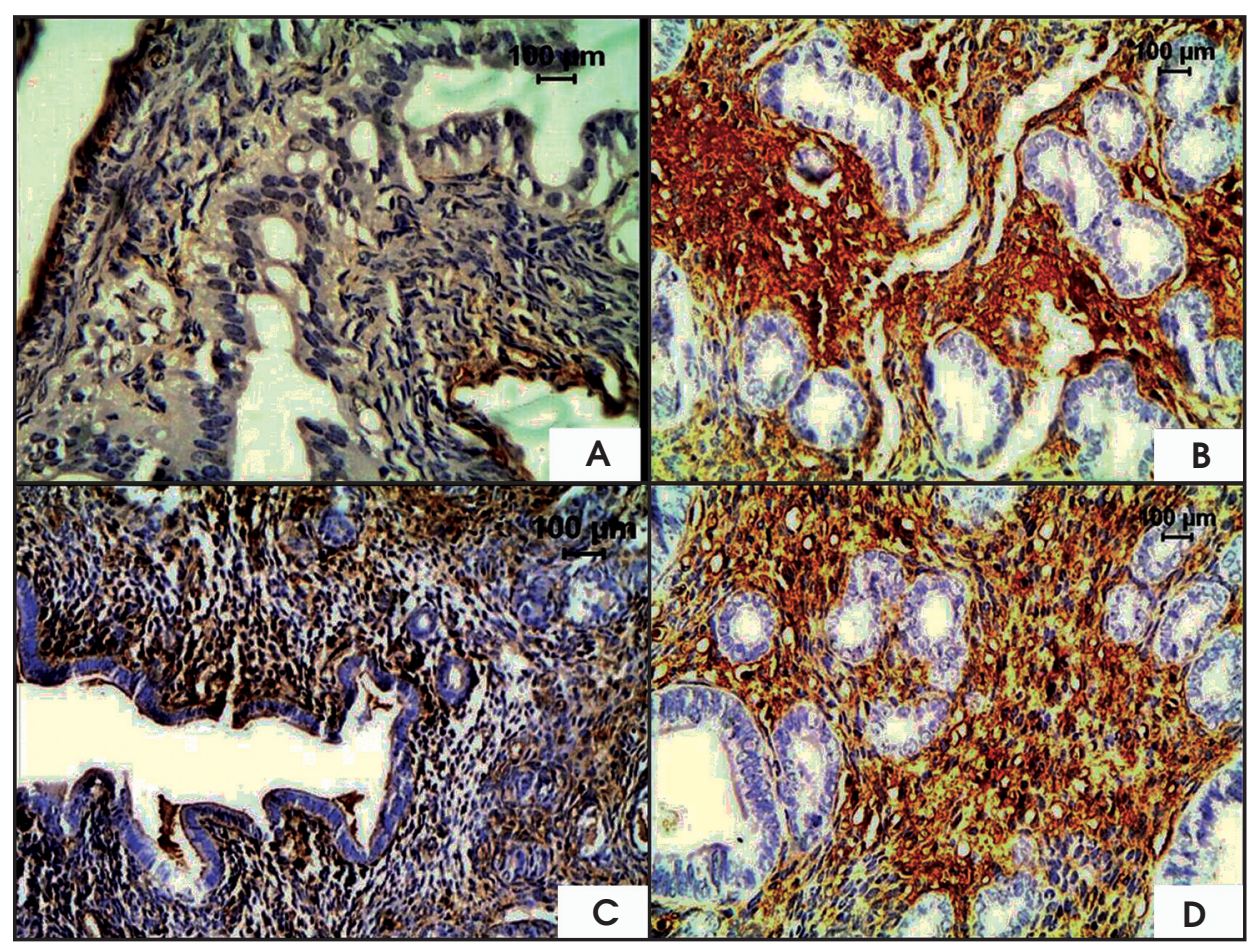

FIGURE 2 - Photographs showing estrogen receptor expression by the nuclei of the uterine epithelial cells in all the groups studied: A) Control proliferative, B) Control secretory, C) Acute Schistosoma infection and D) Chronic Schistosoma infection.

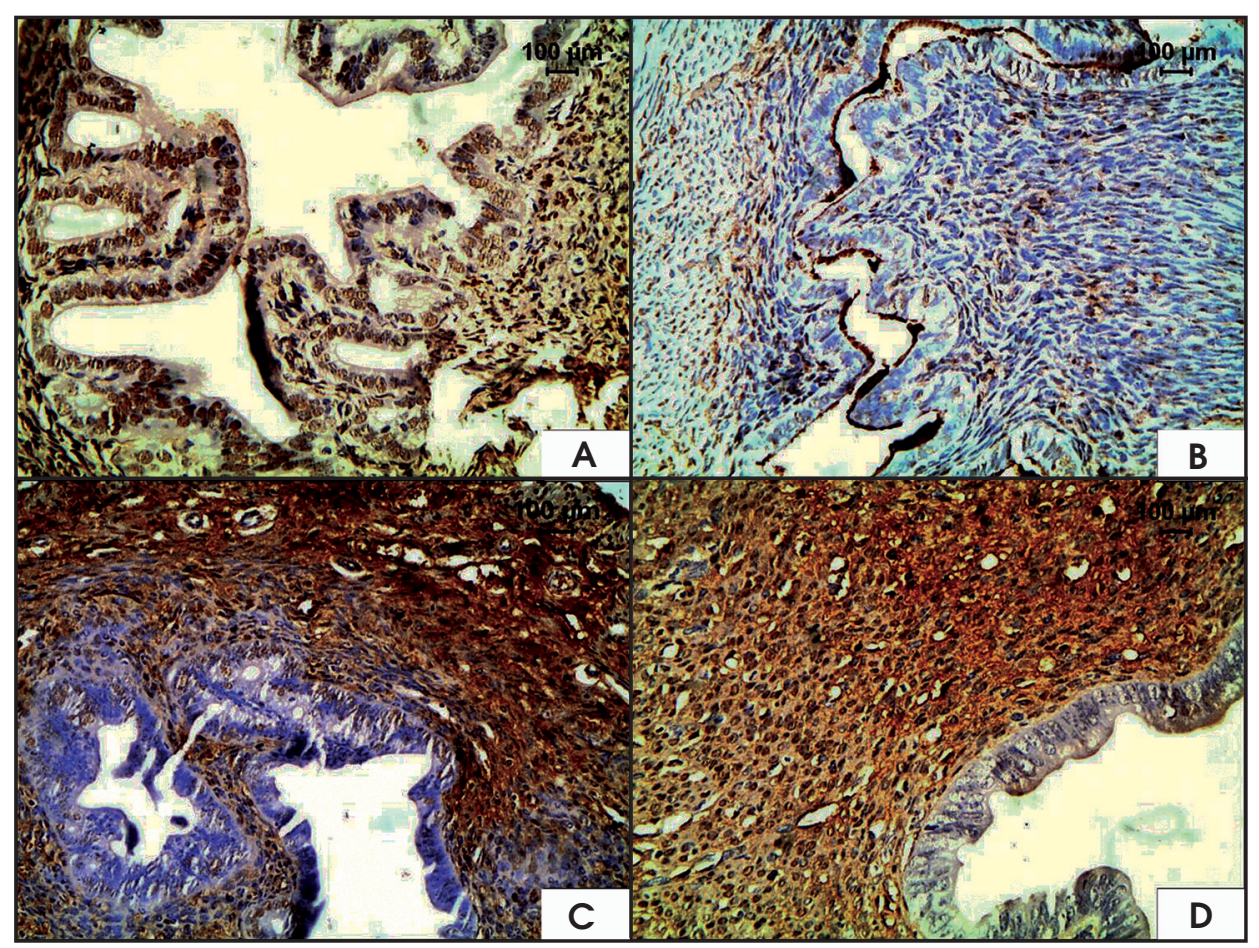

FIGURE 3 - Photographs showing progesterone receptor expression by the nuclei of the epithelial cells in all the groups studied: A) Control proliferative, B) Control secretory, C) Acute Schistosoma infection, and D) Chronic Schistosoma infection.

TABLE 1 - Hormonal receptor expression* in control, acute, and chronic schistosomiasis using anti- estrogen (ER) and anti-progesterone (PR) antibodies.

\begin{tabular}{lccccc} 
& $\begin{array}{c}\text { Control } \\
\text { proliferative } \\
(\mathrm{n}=6)\end{array}$ & $\begin{array}{c}\text { Control } \\
\text { secretory } \\
(\mathrm{n}=6)\end{array}$ & $\begin{array}{c}\text { Acute } \\
\text { schistosomiasis } \\
(\mathrm{n}=8)\end{array}$ & $\begin{array}{c}\text { Chronic } \\
\text { schistosomiasis } \\
(\mathrm{n}=8)\end{array}$ & Significance \\
\hline ER receptors & $3.98 \pm 0.28$ & $4.37 \pm 0.34$ & $4.32 \pm 0.56$ & $0.09 \pm 0.05$ & 0.00 \\
PR receptors & $84.95 \pm 2.84$ & $7.89 \pm 0.44$ & $83.61 \pm 1.51$ & $84.63 \pm 2.44$ & 0.00 \\
\hline
\end{tabular}

*Values are presented as means \pm standard error of mean. ER: estrogen receptor, PR: progesterone receptor. 
proliferative, control secretory and acute infection cases $(\mathrm{P}=0.000)$. No statistically significant differences were was observed between acute infection and any of the control cases (Table 2). In contrast, statistically significant higher PR expression occurred in both acute and chronic infection cases compared to the control secretory cases $(\mathrm{P}=0.000)$ (Table 2).

TABLE 2 - Statistical analysis of hormonal receptor expression in control, acute, and chronic shistosomiasis using Paired-Samples t test.

\begin{tabular}{lcc}
\hline Pairs & $\begin{array}{c}\text { ER } \\
\text { (t- test) }\end{array}$ & $\begin{array}{c}\text { PR } \\
\text { (t- test) }\end{array}$ \\
\hline Control proliferative - acute infection & 0.817 & 0.765 \\
Control proliferative-chronic infection & $0.000^{*}$ & 0.361 \\
Acute infection - chronic infection & $0.000^{*}$ & 0.715 \\
Control secretory- acute infection & 0.718 & $0.000^{*}$ \\
Control secretory-chronic infection & $0.000^{*}$ & $0.000^{*}$ \\
\hline *ignificant at p<0.05 & & \\
ER: estrogen receptor, PR: progesterone receptor. & &
\end{tabular}

\section{DISCUSSION}

Schistosomiasis is a serious and highly prevalent helminthic infection related to water contact and poverty and affects approximately 250 million people living in tropical and subtropical $\operatorname{areas}^{14}$. The number of women with schistosomiasis-related signs and symptoms is likely to be high and could easily involve millions of cases. Numerous published case reports have presented clinical features, often described as unusual, of genital schistosomiasis in female patients. Yet, it is surprising how scarce and unsatisfactory the literature is on this subject ${ }^{15}$. Incidental schistosomiasis of various lesions has been cited in the literature due to both S. mansoni and haematobium; however, insufficient data is available regarding the clinical picture of genital schistosomiasis. Systematic research concerning comorbidities caused by genital involvement during the course of Schistosoma infection is currently sketchy and research on the possible impact of schistosomiasis on different genital problems is still unsatisfactory ${ }^{15}$.

The genital system is usually affected by urinary schistosomiasis caused by haematobium species, with complications including ectopic pregnancies or infertility ${ }^{16-18}$. Concurrently, genital problems due to $S$. mansoni have also been reported in the form of atrophy of the corpus luteum cells and nuclear alterations of the interstitial cells in the ovaries of mice ${ }^{19}$. Farah et $\mathrm{al}^{20}$ reported $S$. mansoni to be a contributing factor in diminished fecundity among women in endemic regions. Numerous authors have emphasized the relation between parasitic and hormonal status in female mice, concluding that not only can host hormones affect responses to infection, but parasites can have pronounced effects on hormone signaling within the host ${ }^{8}$. Moreover, after studying endocrine-immune interactions during parasitic infection, Klein et $\mathrm{al}^{8}$ confirmed the importance of the relation between the endocrine system and parasitic infection. The lack of data concerning hormonal changes associated with Schistosoma infection prompted our group to study the effect of S. mansoni on the hormonal profile of endometrium using immunohistochemical technique.

In the present study, although no direct evidence of S. mansoni infection was detected (no granulomas were observed), alterations in uterine hormone receptor expression were observed. Hormone receptors in the endometrial epithelial cells showed statistically significant higher PR expression in both acute and chronic infection cases as compared to the control secretory cases. This corroborated the histopathological results of the present study, where no secretory glands were observed in the endometrium in either acute or chronic cases, and reflected the expected low progesterone level in both cases.

Regarding ER expression, chronic cases showed statistically significant low ER hormone expression compared to that of both control proliferative and secretory cases, whereas no significant changes occurred in ER expression in acute infection cases compared to any of the control cases. This also coincides with the detection of late proliferative endometrium, which was observed in this study, and reflects the expected high estrogen level in chronic infection cases. These results explore the negative impact of $S$. mansoni on the female genital system, even in the absence of direct lesional infectious stages. Such observations might explain the infertility that has been attributed to Schistosomiasis infection by some authors ${ }^{5,20}$.

Hormonal alteration is also recorded in males during S. mansoni infection, since it suppresses testosterone production in male mice ${ }^{21}$. Alterations in hormone receptors in the present study might be due to the toxic effect of such hemoparasites on female hormones. These results are in agreement with those obtained by Klein et $\mathrm{al}^{\mathbf{8}}$, who reported increased concentration of serum oestradiol and progesterone levels and serious complications in genital system during hemoparasite Plasmodium infection. To our knowledge, no data exists concerning the findings described in the present work and this study seems to be the first report regarding uterine estrogen and progesterone hormone receptors in cases of Shistosoma mansoni infection.

From the data obtained, it is clear that genital infection by schistosomiasis worsens the disease burden of women in the child bearing period. Pathological consequences can be damaging for the affected women. A lack of clinical awareness of genital schistosomiasis can lead to misdiagnosis and therefore false and ineffective therapy. Therefore, future studies concerning the effect of different species of schistosomes are recommended to current understanding and to explore the possible mechanisms of such changes during both acute and chronic infection.

\section{CONFLICT OF INTEREST}

The authors declare that there is no conflict of interest.

\section{REFERENCES}

1. Hu W, Brindley PJ, McManus DP, Feng Z, Ze-Guang H. Schistosome transcriptomes: new insights into the parasite and schistosomiasis. Trends Mol Med 2004; 10:217-222.

2. Friedman JF, Mital P, Kanzaria HK, Olds GR, Kurtis JD. Schistosomiasis and pregnancy. Trends Parasitol 2007; 23:159-164.

3. Giese GH, Kjetland EF, Gundersen SG, Poggensee G, Richter J, Krantz I, et al. Schistosomiasis in women: manifestations in the upper reproductive tract. Acta Tropica 1996; 62:225-238.

4. Kjetland FE, Poggensee G, Helling-Giese G, Richter J, Sjaastad A, Chitsulo L, et al. Female genital schistosomiasis due to Schistosoma haematobium Clinical and parasitological findings in women in rural Malawi. Acta Tropica 1996; 62:239-255.

5. Harouny A, Pedersen H. Pelveo-peritoneal schistosomiasis as a cause of primary infertility. Int J Gynaecol Obstet 1988; 27:467-469. 
6. Balasch J, Martínez-Román S, Creus M, Campo E, Fortuny A, Juan A. Vanrell Schistosomiasis: an unusual cause of tubal infertility, European Society of Human Reproduction and Embryology. Hum Reprod 1995; 10:1725-1727.

7. Morice P, Chapron C, Vacher Lavenu MC, Terrasse G, Dubuisson JB. Genital bilharziasis and female infertility. Review of the literature and three case reports. Contracept Fertil Sex 1996; 24:56-61.

8. Klein SL. Hormonal and immunological mechanisms mediating sex differences in parasite infection. Parasite Immunol 2004; 26:247-264.

9. De Clercq D, Vercruysse P, Verle A, Kongs J, Diop V. What is the effect of combining artesunate and praziquantel in the treatment of Schistosoma mansoni infections? Trop Med Int Health 2002; 5:744-746.

10. Bancroft JD, Gamble M. Theory and Practice of Histological Techniques. Churchill Livingstone editors. London, New York; 1996. p.137.

11. Viacava P, Gasperi M, Acerbi G, Manetti L, Cecconi E, Naccarato AF. Microvascular density and vascular endothelial growth factor expression in normal pituitary tissue and pituitary adenomas. J Endocrinol Invest 2003; $26: 23-28$

12. Winters ZE, Leek RD, Bradburn MJ, Norbury CJ, Harris AL. Cytoplasmic p21WAF1/CIP1 expression is correlated with HER's-2/neu in breast cancer and is an independent predictor of prognosis. Breast Cancer Res 2003; 5:R242-249.

13. Charpin C, Dales JP, Garcia S, Carpentier S, Djemli A, Andrac L, et al. Tumor Neoangiogenesis by CD31 and CD105 Expression Evaluation in Breast Carcinoma Tissue Microarrays. Clinical Cancer Res 2004; 10:5815-5819.

14. Chitsulo L, Engels D, Montresor A, Savioli L. The global status of schistosomiasis and its control. Acta Trop 2000; 77:51

15. Swai B, Poggensee G, Mtweve S, Krantz I. Female genital schistosomiasis as an evidence of a neglected cause for reproductive ill-health a retrospective histopathological study from Tanzania. BMC Infect Dis 2006; 6:134.

16. Scheller R. Genitalbilharziose Extrauteringravidität. Zbl Gynäkol 1974; 96:88-92.

17. Bughalo A, Strolego F, Benussi G, Pregazzi R, Osamn N. Schistosomiasis possibile case di gravidanza ectopica. Minerva ginecol 1991; 43:577-579.

18. Picaud A, Walter P, Bennani S, Minko ME, Nlome NA. Fallopian tube bilharziasis caused by Schistosoma intercalatum disclosed by hemoperitoneum. Arch Anat Cytol Pathol 1990; 38:208-211.

19. Tiboldi T. Reversibility of Histopathological changes in the Ovaries in Acute Murine Schistosomiasis Mansoni after Niridazole Treatment. Am J Trop Med Hyg 1979; 28:1026-1030.

20. Farah I, Andersson E, Mwenda J, Wango E, Hau J. Schistosomiasis (mansoni) has a negative impact on serum levels of estradiol, progesterone and prolactin in the female baboon (Papio cynocephalus anubis). Scand J Lab Anim Sci $2001 ; 28$ :issue 4.

21. Isseroff H, Sylvester P, Held W. Effects of Schistosoma mansoni on androgen regulated gene expression in the mouse. Mol Biochem Parasitol 1986; 18:401-412. 